\title{
STRATEGIC PLANNING AND BUSINESS PERFORMANCE: AN EMPIRICAL STUDY OF MANUFACTURING SMES IN WESTERN PROVINCE
}

\author{
By \\ Wijetunge Arachchige Deepani Sajeewa Wijetunge \\ (Index No. 5266FM2010144)
}

A research submitted to the University of Sri Jayewardenepura in partial fulfillment of the requirements for the Degree of Master of Business Administration (General) on 21.02.2013 


\section{Declaration of the candidate}

The work described in this research was carried out by me under the supervision of Dr. (Mrs.) M.D. Pushpakumari and a report on this has not been submitted in whole or in part to any university or any other institution for another Degree/ Diploma.

Signature of the student

Full name of the student

Registration No

Year of submission

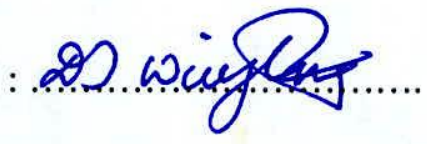

: Wijetunge Arachchige Deepani Sajeewa Wijetunge : 5266FM2010144

: 2013 


\section{Declaration of the Supervisor}

I certify that the above statement made by the candidate is true and that this research is suitable for submission to the University for the purpose of evaluation.

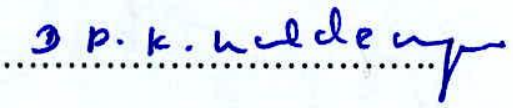

Signature

Dr. (Mrs.) M.D. Pushpakumari

Senior Lecturer

Department of Business Administration

Faculty of Management Studies and Commerce

University of Sri Jayewardenepura
$25|04| 2013$

Date 


\section{TABLE OF CONTENTS}

Page no

Table of Contents

$\mathrm{v}$

List of Tables

ix

List of Figures

xii

List of Abbreviations

xiii

Acknowledgements

XV

Abstract

xvi

Chapter 01: Introduction

1.1 Background of the Study

1.2 Problem Statement

1.3 Research Objectives

1.4 Research Methodology

1.5 Significance of the Study

1.6 Limitations of the Study

1.7 Organization of Chapters

Chapter 02: Literature Review

2.1 Introduction

2.2 The Need/Importance of Planning

2.3 Definitions and Content of Strategic Planning

2.4 Strategic Planning Practices of SMEs

2.5 Reasons for Less Practices of Strategic Planning in SMEs

2.6 Factors Affecting the Strategic Planning

2.7 Owner/Manager Characteristics and Firm Characteristics for the Involvement to the Process of Strategic Planning in SMEs

2.8 Entrepreneurial Orientation (EO)

2.9 Entrepreneurial Orientation and Planning

2.10 Business Performance

2.11 Strategic Planning and Performance 36

2.12 Entrepreneurial Orientation (EO) and Performance 
Chapter 03: Small and Medium sized Enterprises (SMEs)

3.1 Introduction 48

3.2 The Evolution and Importance of SMEs 48

3.3 Definitions of SMEs $\quad 53$

3.4 The Importance of Developing SMEs in Sri Lanka 57

3.5 Profile Characteristics and Position of SME Sector in Sri Lanka 60

3.6 The Policy and Institutional Environment of SMEs in Sri Lanka 60

3.7 The Tribulations Encountered by SMEs 68

$\begin{array}{lll}3.8 & \text { Summary } & 69\end{array}$

$\begin{array}{ll}\text { Chapter 04: Research Design and Methodology } & 70\end{array}$

$\begin{array}{lll}4.1 & \text { Introduction } & 70\end{array}$

$\begin{array}{lll}4.2 & \text { Research Design } & 70\end{array}$

$\begin{array}{lll}4.3 & \text { Conceptual Framework } & 71\end{array}$

$\begin{array}{lll}4.4 & \text { Research Hypotheses } & 73\end{array}$

$\begin{array}{lll}4.5 & \text { Identification and Measurement of Variables } & 74\end{array}$

4.5.1 Owner/Manager Characteristics and their Indicators 74

4.5.2 Firm Characteristics and their Indicators 75

4.5.3. Entrepreneurial Orientation 76

$\begin{array}{lll}\text { 4.5.4 Strategic Planning Process } & 77\end{array}$

$\begin{array}{lll}\text { 4.5.5 Business Performance } & 80\end{array}$

$\begin{array}{lll}\text { 4.6 Population, Sample and Sampling Method } & 80\end{array}$

$\begin{array}{lll}4.7 & \text { Data Collection Method } & 84\end{array}$

4.8 Design and Administration of Questionnaire $\quad 85$

4.9 Validity and Reliability Evidences $\quad 85$

\begin{tabular}{ll}
4.10 & Data Analysis Method \\
\hline
\end{tabular}

$\begin{array}{lll}4.11 \text { Summary } & 91\end{array}$ 
5.1 Introduction 92

5.2 Exploratory Data Analysis (EDA) 92

5.2.1 Testing for Normality 92

5.2.2. Testing for Linearity 93

5.2.3. Testing for Multicollinearity 94

5.2.4 Testing for Homoscedasticity 94

5.3 Descriptive Analysis of the Sample Characteristics 95

5.3.1 The Profile Characteristics of SME Owner/Managers 95

5.3.2. The Profile Characteristics of SMEs 97

5.4 Strategic Planning Practices in SMEs in Sri Lanka 100

5.5 The Relationship Between the Strategic Planning Process (SPP) 102 and the Business Performance (BP)

5.6 Barriers Encountered by SMEs in Engaging in Strategic Planning 109 Process

5.7 The Relationship between Owner/Manager and Firm Characteristics 110 of SMEs and the Level of Involvement in the Strategic Planning Process

5.7.1 The Relationship between Owner/Manager Characteristics of 111 SMEs and the Level of Involvement in the Strategic Planning Process

5.7.2 The Relationship between Firm Characteristics of SMEs and the Level of Involvement in the Strategic Planning Process

5.8 The level of Entrepreneurial Orientation (EO) of Owner/Managers of SMEs and its Impact on Strategic Planning Process and Business Performance

5.8.1 The level of Entrepreneurial Orientation (EO)

5.8.2 The Entrepreneurial Orientation (EO) of Owner/Managers 123 of SMEs and Strategic Planning Process

5.8.3 The Entrepreneurial Orientation (EO) of Owner/Manager of SMEs and its Impact on Business Performance

$\begin{array}{ll}5.9 \text { Other Findings of the Study } & 129\end{array}$

5.10 Summary 131 
Chapter 06: Discussion of the Results

6.1 Introduction 132

6.2 Discussion of the Results Related to the Major Findings 132

6.2.1 Strategic Planning Practices in SMEs 132

6.2.2 The Relationship between Strategic Planning Process 134 and Business Performance of SMEs

6.2.3 Barriers Faced by SMEs in Engaged in Strategic Planning Process 136

6.2.4 Relationship between owner/manager and firm characteristics 137 of SMEs and the level of involvement in the strategic planning process

6.2.5 The Relationship between the level of Entrepreneurial Orientation 140 (EO) of Owner/managers of SMEs and Involvement to the Process of Strategic Planning

6.2.6 The Relationship between the Entrepreneurial Orientation (EO) of Owner/managers of SMEs and Business Performance

\subsection{Summary}

Chapter 07: Summary and Conclusions

7.1 Introduction

7.2 Summary

7.3 Conclusions Drawn From the Study

7.4 Implications, Suggestions and Recommendations of the Research

7.5 Limitations and Recommendations for Further Research

\section{References}

\section{Appendices}

Appendix A: Survey Questionnaire 


\section{List of Tables}

Page No.

$\begin{array}{ll}\text { Table 2.1: Classification of Strategic Planning } & 14\end{array}$

Table 2.2: Categorization of Strategic Plans 16

$\begin{array}{ll}\text { Table 2.3: Strategic Planning Categories } & 17\end{array}$

Table 2.4: Components of Strategic Planning Process 19

Table 2.5: Indicators of Strategic Posture 29

Table 2.6: Indicators of Entrepreneurial Orientation (EO) 30

Table 2.7: Dimensions of Entrepreneurial Orientation 31

Table 2.8: Measures of Financial Performance 33

Table 2.9: Indicators of Performance 34

Table 2.10: Empirical Studies of the Relationship between Strategic Planning 43 and Performance

Table 3.1: Contribution of SME Sector for the Gross Domestic Product (GDP) in 50 Selected Asian Countries in 2006

Table 3.2: Definitions of SMEs in Selected Asian Developing Countries 54

Table 3.3: Definitions of SMEs in Sri Lanka 56

Table 3.4: Principal Indicators of Industrial Activity Classified by Major Industry 57

Division \& Persons Engaged size Class - 2009 (Establishments with 5 or more Persons Engaged)

Table 3.5: Principal Indicators of Industrial Activity Classified by District - 200959

(Establishments with 5-100 Persons Engaged) (Manufacturing Sector)

Table 3.6: Sector wise Loan Disbursement - 2011 67

Table 4.1: Owner/Manager Characteristics and their Indicators 75

Table 4.2: Firm Characteristics and their Indicators 76

Table 4.3: Indicators of Entrepreneurial Orientation $\quad 77$

Table 4.4: Indicators of Strategic Planning Process $\quad 78$

Table 4.5: District wise Manufacturing SMEs in Sri Lanka 82

Table 4.6: Distribution of the Sample $\quad 83$

Table 4.7: Distribution of Manufacturing SMEs in each district under each $\quad 83$ industry division in Western Province

Table 4.8: Industry wise Selection of SMEs in Western Province 84 
Table 4.9: KMO and Bartlett's Test: Pilot Study

Table 4.10: Cronbach's Alpha Statistics of Scales: Pilot Study and Main Study

Table 411: Summary of the Statistical Methods and Tools of the Study

Table 5.1: Multicollinearity Test of Independent Variables of Conceptua

Framework

Table 5.2: The Personal Profile of the Owner/Managers

Table 5.3: General Profile of SMEs

Table 5.4: Reason to Start Current Business

Table 5.5: Strategic Planning Practices of Manufacturing SMEs in Western province

Table 5.6: Relationship between Strategic Planning Process and Business

Performance

Table 5.7: Relationship between Each Step of the Strategic Planning Process and 104 Business Performance

Table 5.8: Relationship between Overall Strategic Planning Process and the Each 105 Indicator of Business Performance

Table 5.9: Relationships between Steps of Strategic Planning Process and the 106

Variables of Business Performance

Table 5.10: SMEs by Level of Involvement in the Strategic Planning Process

Table 5.11: Most Important Barrier in Strategic Planning

Table 5.12: Level of Involvement in the Strategic Planning process by the Age of the Owner/Manager

Table 5.13: Level of Involvement in the Strategic Planning process by the Gender 113 of the owner/manager

Table 5.14: Level of Involvement in the Strategic Planning Process by the

Highest Education Level of the Owner/Manager

Table 5.15: Level of Involvement in the Strategic Planning Process by the

Previous Training of the Owner/Manager

Table 5.16: Level of Involvement in the Strategic Planning Process by the

Previous Business Experience of the Owner/Manager

Table 5.17: Level of Involvement in Strategic Planning Process by the Firm Size 118

Table 5.18: Level of Involvement in the Strategic Planning Process by the Age 119 
of the Firm

Table 5.19: Level of Involvement in Strategic Planning Process by the Legal

Form of the Firm

Table 5.20: SMEs by Level of Entrepreneurial Orientation

Table 5.21: Relationship between Entrepreneurial Orientation and Strategic

Planning Process

Table 5.22: Relationship between the EO and Business Performance

Table 5.23: Relationship between Dimensions of EO and Business Performance 125

Table 5.24: Relationship between Overall EO and each Measure of Business

Performance

Table 5.25: Relationship between EO Dimensions and Business Performance Indicators

Table 5.26: Multiple Regression Analysis - Dimensions of EO and Business

Performance

Table 27: ANOVA - EO and Business Performance 


\section{List of Figures}

Page no.

Figure 3.1: Output Growth Rates of Small Enterprises (SEs), Medium

Enterprises (MEs) and Large Enterprises (LEs) (\%) (2001-2006) in Asian

Developing Countries

Figure 3.2: GDP Growth Contribution by Size of Enterprise (\%) in Asian

Developing Countries (2003 - 2006)

Figure 3.3: SME Sector Contribution to Total Employment and GDP in Asian

Countries (2000-2004)

Figure 3.4: District wise Loan Disbursement - 2011 (Rs. Millions)

Figure 4.1: Factors affecting the Strategic Planning and its Impact on Business

Performance

Figure 5.1: Major Areas of Manufacturing

Figure 5.2: Most Important Competitive Factor of the Business

Figure 5.3: Most Important Barrier of the Business

Figure 5.4: The Next Step of the Business 
List of Abbreviations

ADB Asian Development Bank

ANOVA Analysis of Variance

CISIR Ceylon Institute of Scientific and Industrial Research

CSSI Cottage and Small Scale Industry

DCS Department of Census and Statistics

EDA Exploratory Data Analysis

EDB Export Development Board

EDPs Entrepreneurship Development Programmes

EO Entrepreneurial Orientation

FTE Full Time Employee

GDP Gross Domestic Product

IDB Industrial Development Board

IFC International Finance Corporation

LEs large enterprises

MEs Micro Enterprises

MFP Ministry of Finance and Planning

MSSA Micro and Small Scale Activities

NCC National Craft Council

NDB National Development Bank

NDC National Designed Centre

NIBM Institute of Business Management

NYSCO National Youth Co-operatives

REs Rural Enterprises

RRDB Regional Rural Development Bank

SEDD Small Business Development Division

SEs Small Enterprises

SLBDC Sri Lanka Business Development Center

SLHB Sri Lanka Handicraft Board

SMAs Small and Medium Scale Activities

SMED Small and Medium Enterprise Developers 


$\begin{array}{ll}\text { SMEDeF } & \text { Small and Medium Enterprise Development Facility Project } \\ \text { SMERDP } & \text { Small and Medium Enterprise Regional Development Project } \\ \text { SMEs } & \text { Small and Medium sized Enterprises } \\ \text { SMIDEC } & \text { Small and Medium Industries Development Corporation } \\ \text { SMIs } & \text { Medium Scale Industries } \\ \text { SPP } & \text { Strategic Planning Process } \\ \text { TF } & \text { Task Force } \\ \text { VIF } & \text { Variance Inflation Factor }\end{array}$




\section{Acknowledgement}

I would like to first pay my respect and sincere gratitude to my Academic Advisor Dr. (Mrs.) M.D. Pushpakumari for her guidance, precious advice and the assistance through the entire research. Without her encouragement and persistence help, this research would not have been possible during the periods that I faced a lot of hardship in my life.

I express my thankfulness to the former Coordinator of MBA programme, University of Sri Jayewardenepura Dr. P.D. Nimal, and the panel of lecturers who provide us the tremendous theoretical and practical knowledge during our entire degree programme and the non academic staff members of the Centre for Management Studies, University of Sri Jayewardenepura for their enthusiastic support.

I wish to express my gratefulness to Mrs. S. Amaratunge, Former Head of the Department of Commerce and Financial Management, Dr. C. Pathirawasam, Head of the Department of Commerce and Financial Management for releasing my work load, and my colleagues for their invaluable encouragement during my research. Further I would like to extend my gratitudes to Dr. C.N. Wickramasinghe for the guidance and assistance provided for the research as academicians. Further I would like to thank Ms. Thushari Kamalawansa, English Instructor attached to the Department of English, University of Kelaniya for assisting me in language editing.

Special thanks are due for Mrs. Sanjeewani, Mr. Newton at Department of Census and Statistics and Mr. Madhawa Waidyaratna, former Deputy Director, Sri Lanka Export Development Board for providing me the industry support.

Also I would like to express my gratitude to Mr. Sameera and his team for supporting me in conducting interviews with the owner/managers of SMEs. I'll not be able to success in gathering information without their commitment.

Finally, I would like to thank my husband, Mr. B.A.S.L. Balasooriya and my daughter Nethumi Thulsandi for keeping endurance when I devote their time for my studies. Also the encouragement given by my mother, father and my brother is greatly appreciated.

W.A.D.S. Wijetunge 


\title{
Strategic Planning and Business Performance: An Empirical Study of Manufacturing SMEs in Western Province
}

\author{
W.A.D.S. Wijetunge
}

ABSTRACT

The economic growth of developing countries can be sustained by the expansion of private sector, as they are the engine of growth. As a consequence, it is important to accelerate the growth of SMEs in order to gain sustainable development in this era. Many scholars have argued that the strategic planning is one of the salient factors which contribute to the performance of SMEs. However the recent literature provides contradictory findings about the relationship between strategic planning and performance. Based on these evidences, the main objective of the study was to examine the relationship between strategic planning and performance of SMEs. More importantly the study focused on strategic planning process where, there is a dearth of studies which have concentrated on strategic planning process. Specific objectives include to identify the strategic planning practices in SMEs, to examine the difficulties faced by SMEs in engaged in strategic planning process, to identify the relationship between owner/manager and firm characteristics of SMEs and the level of involvement in the strategic planning process, to investigate the level of Entrepreneurial Orientation (EO) of owner/managers of SMEs and its impact on strategic planning process and business performance. Data were collected through personally attended structured questionnaire distributed among 275 owner/managers of SMEs in Western province. Both descriptive and inferential statistics techniques were used to analyze the collected data. 
The findings revealed that the SMEs are highly engaged in strategic planning process and there is a positive relationship between strategic planning and business performance. When SMEs are involved more in strategic planning process leads to high business performance. Further, owner/manager characteristics such as age, gender, educational qualifications, prior training and previous business experience are positively related to involvement in the strategic planning process. Further, the Entrepreneurial Orientation (EO) among owner/managers of manufacturing SMEs in Western province is observed high level. Among the dimensions of EO, innovativeness shows high influence on business performance. Overall, the findings of the study could provide useful insights for owner/managers of SMEs. 